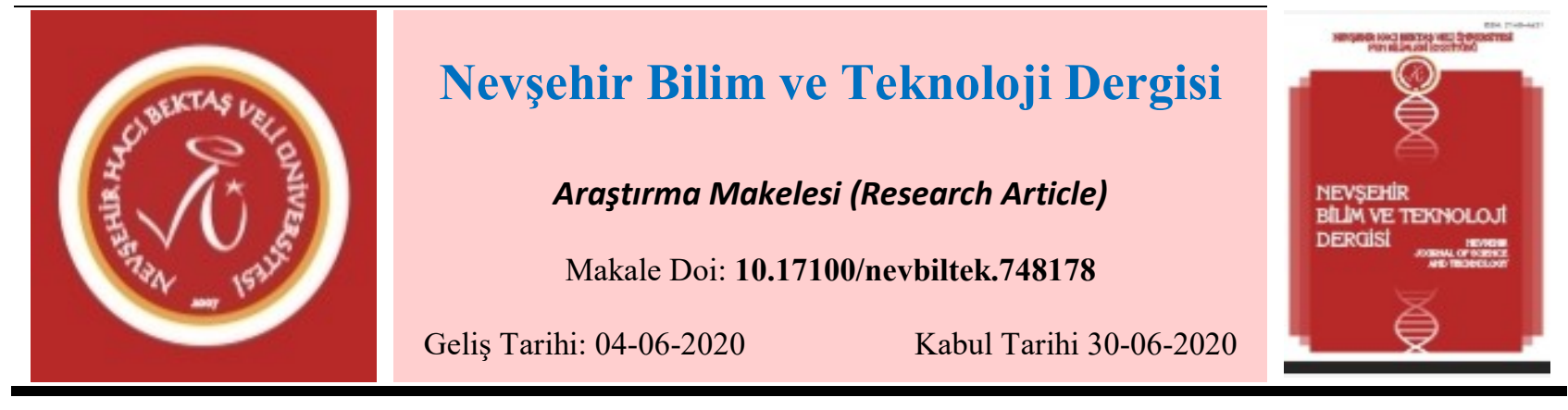

\title{
Nitrür Esaslı Malzemelerin Yüksek Enerjili Öğütme ile Düşük Maliyetli Üretimi
}

\author{
Semra KURAMA ${ }^{1,}$, Haldun KURAMA ${ }^{2}$ \\ ${ }^{1}$ Eskişehir Teknik Üniversitesi, Mühendislik Fakültesi, Malzeme Bilimi ve Mühendisliği Bölümü, Eskişehir \\ ORCID ID: 0000-0002-7554-3419 \\ ${ }^{2}$ Eskişehir Osmangazi Üniversitesi, Mühendislik Fakültesi, Maden Mühendisliği Bölümü, Eskişehir \\ ORCID ID: 0000-0002-2773-8326
}

Öz

Seramik malzemelerin üretiminde, hem performans artışı hem de ekonomi en önemli iki parametredir. Bu iki işlemin yönetimindeki ortak parametre, hammaddelerin başlangıçtaki toz boyutunun kontrol edilmesidir. Nitrür bazlı ileri teknoloji malzemeleri, saflıkları ve üretim sürecindeki mikron boyutları nedeniyle önemli avantajlar sağlar. Bununla birlikte, bu malzemelerin sinterlenmesi hem zor hem de pahalıdır. Sinterleme işleminde kullanılan katkı maddeleri, nihai üründe malzemenin kullanım özelliklerinde bozulmaya neden olabilir. Özellikleri, sertliği ve aşındırıcılığı nedeniyle, öğütme işlemini kullanarak partikül boyutlarını istenen boyuta düşürmek kolay bir şekilde mümkün değildir. Bununla birlikte, tozların süspansiyonda askıda tutulması ile bu işlemi aktif, kısa ve verimli hale getirmek mümkündür. Bu nedenle, sistemdeki toz-toz, toz-bilya etkileşimini arttırmak mümkündür. Bu çalışmada, süreç farklı stabilizatörler ve ortam kullanılarak kontrol edilmiştir. Böylece, tane büyüklüğü $500 \mu$ m olan nitrür tozlarının boyutu 100nm'ye düşürülmüş, bu da sinterleme ve mekanik davranışların iyileştirilmesi ile sonuçlanmıştır.

Anahtar Kelimeler: Bilyalı ögütme; Nitrür tozları; Karışım; Nano toz

\section{Cost Effective Production of Nitride Based Materials by High Energy Ball Milling}

\begin{abstract}
In the production of ceramic materials, both performance increase and economy are the two most important parameters. The common parameter in the management of these two processes is the control of the initial powder size of the raw materials. Nitride-based advanced technology materials provide significant advantages due to their purity, and micron size in the production process. However, the sintering of these materials is both difficult and expensive. The additives used in the sintering process may cause deterioration in the using properties of the material in the final product. Due to its properties, hardness and abrasiveness, it cannot be easily possible reduce their particle size to the desired size using the grinding process. However, it is possible to make this process be active, short and efficient by suspending the powders in suspension. Therefore, it is possible to increasing the powderpowder, powder-ball interaction in the system. In this study, the process was controlled by using different stabilizers and medium. Thus, the size of nitride powders having a grain size of $500 \mu \mathrm{m}$ was reduced to $100 \mathrm{~nm}$, resulting in improved sintering and mechanical behavior.
\end{abstract}

Keywords: Ball milling; Nitride powders; Medium; Nano powder 


\section{Nevşehir Bilim ve Teknoloji Dergisi (2019), 9 (IMSTEC Özel Sayı),79-85}

\section{Introduction}

Nanocrystalline materials as powders, composite or metals forms with a grain sizes usually in the range 10-300 nm, have been of interest more than 20 years and this interest looks like to continue in near future. The main reason of this can be attributed to their unusual properties based on the high concentration of atoms in interfacial structures. [1-4]. Nanocrystalline materials are generally characterized by a large volume fraction of grain boundaries. The extremely small size of the grains and the increased fraction of the atoms located in the grain boundaries lead significant improvement on the mechanical, chemical and physical properties of the powder and thus the material exhibits enhanced combinations of physical, mechanical, and magnetic properties. Except than the structural advantages, the relatively simple ways of their preparation has also made them most widely used material in numerous industrial applications. One of the most common and important application of nano materials can be given for the structural ceramics. Structural ceramics are the most desirable industrial materials because of their excellent mechanical properties, such as strength, fracture toughness, wear resistance and hardness [5]. Within this group, silicon nitride $\left(\mathrm{Si}_{3} \mathrm{~N}_{4}\right)$ and its solid solutions is remarkably distinguished from the others especially for high-temperature applications. It has excellent strength and toughness at elevated temperatures, good thermal shock resistance, low coefficient of thermal expansion, and the chemical stability [6].

The pressureless/pressured gas sintering, hot isostatic pressing or spark plasma sintering methods are the main methods for the production of silicon nitride based ceramics in commercial applications. Most of them the $\mathrm{Y}, \mathrm{Ca}, \mathrm{Mg}$ or rare-earth oxides are used to provide need liquid phase for densification of the material during sintering [7-8]. However, the remaining of these liquid phase as amorphous or even as crystalline phases after sintering is limited the gaining of desired final properties due to decreased corrosion resistance [9-11]. Therefore, in recent years, the must be stabilized against aggregation. This is frequently performed by addition of the grinding aids/process control agent (inorganic or organic surfactants) into the system. Previous studies performed by Xu et al. indicated that use of polymeric surfactants positively affect the average particle size of the milled powders [12]. However, the choice of polymer surfactants varies from case to preparation of SiAlON ceramics with nano-size precursor powders has received considerable interest as an effective method for both improving the high providing desired decrease on the sintering temperature [13-16]. In these routes, different from the conventional particle size reduction or comminution in which the powder particles either remain unchanged or are fractured into smaller particles, the powder synthesize are mostly performed in a non-equilibrium state by "energizing and quenching". The energization mainly involves bringing the material into a highly non-equilibrium (metastable) state by some external dynamical forcing, e.g., through melting, evaporation, irradiation, application of pressure, or storing of mechanical energy by plastic deformation. Therefore, for the production nano-structured materials, the milling is performed by high-energy forms to provide needed energy for plastic deformation. Rather than the derivable of need energy, the ability to produce bulk quantities of material in the solid state at room temperature with simple equipment has been found further benefit of the usage of mechanical milling, MM [14, 17-19].

As discuses above, the main advantages of the MM in SiAlON ceramics production is the preparation of the material that having a finesse particle size suitable for further stages. However, this particle size reduction is, in many cases, complicated by particle size enlargement due to particle-particle interaction as the result of van der Waals adhesion forces [20].

Particles in the nanometer size range have a strong tendency to agglomerate owing to their relatively large specific surface area which cause enhancement of their van der Waals interactions between them. Therefore, they case and it should be realized that there is no universal surfactant. One of the other important issues for MM is the nature of the grinding process. Dry fine grinding process is the well-employed method for the produce of nano-sized powder. The surfactant added grinding process generally resultant with lower rate of amorphization and decrease the contamination. Nevertheless, it has been reported that, applications of wet grinding are a more suitable method than dry grinding to obtain finer-ground powders because the solvent molecules are adsorbed on the newly formed surfaces of the particles and lower their surface energy. The less-agglomerated condition of the powder particles in the wet condition is also found as a useful factor for grinding processes [19].

Consequence, in literature, several attempts on SiAlON production showed that addition of nano powders resultant with very encourageable out comes on the structure properties. However, the observed limitations such as increased impurity content of the milled powder due to erosion of vial and balls, non-homogenous grain size distribution and difficulties to obtain nano sized powder due to agglomeration tendency of the fine particles especially for lower ball to powder ratio necessitates the re-evaluate milling stage. Therefore, in this study, the effect of process control agent's type and their ratio on the morphology and particle size of nitride based powders was investigated in detail. 


\section{a. Material}

In this study, the $\beta$-SiAlON composition, $\mathrm{Si}_{6-z} \mathrm{Al}_{z} \mathrm{O}_{z} \mathrm{~N}_{8-\mathrm{z}}$, where the $\boldsymbol{z}$ value is 2 , is prepared from a mixture of $\mathrm{Si}_{3} \mathrm{~N}_{4}, \mathrm{AlN}, \mathrm{Al}_{2} \mathrm{O}_{3}$ and $\mathrm{Y}_{2} \mathrm{O}_{3}$. The properties of the powders are given at Table 1 .

\begin{tabular}{|c|c|c|}
\hline Raw Materials & $\begin{array}{c}\text { Impurity } \\
\text { (wt.\%) }\end{array}$ & $\begin{array}{r}\text { Phases } \\
(\%)\end{array}$ \\
\hline $\mathrm{Si}_{3} \mathrm{~N}_{4}(\mathrm{UBE}-\mathrm{E} 10)$ & $1.6 \mathrm{O}$ & $\begin{array}{c}95 \alpha-\mathrm{Si}_{3} \mathrm{~N}_{4} \\
5 \beta-\mathrm{Si}_{3} \mathrm{~N}_{4}\end{array}$ \\
\hline $\mathrm{Al}_{2} \mathrm{O}_{3}(\mathrm{AKP} 50)$ & $\begin{array}{c}0.08 \mathrm{Na}_{2} \mathrm{O} \\
0.03 \mathrm{SiO} \\
0.03 \mathrm{CaO}\end{array}$ & $100 \mathrm{Al}_{2} \mathrm{O}_{3}$ \\
\hline AlN (Tokuyama) & $1.0 \mathrm{O}$ & $100 \mathrm{AlN}$ \\
\hline $\mathrm{Y}_{2} \mathrm{O}_{3}$ (Aldrich) & - & $100 \mathrm{Y}_{2} \mathrm{O}_{3}$ \\
\hline
\end{tabular}

\section{b. Method}

The milling of samples was performed by high-energy mechanical mill (Pulverisette 6 Fritsch, Germany). In experiments, two different preparation routes were concerned to observe the process variables effects on milled products. In the first route, the powders were mixed with 5 wt. $\% \mathrm{Y}_{2} \mathrm{O}_{3}$ and placed in to the vial that filled with approx. 2/3\% (v) isopropanol alcohol. The vial was closed and milled for $1.5 \mathrm{~h}$ at $300 \mathrm{rpm}$ using the $\mathrm{Si}_{3} \mathrm{~N}_{4}$ balls. The ball to powder ratio, BPR, was 1:1.5. The obtained powder by this method is denoted as "conventional milled powder, $\boldsymbol{C}_{\boldsymbol{M}}$ ", due to the generally preferred way in literature. At the second route, the BPR was employed as 12:1 according to filling suspension volume of $10 \%$ in a closed packed system of $\mathrm{Si}_{3} \mathrm{~N}_{4}$ balls (of $5 \mathrm{~mm}$ radius and $9 \mathrm{~mm}$ length). The milling studies for this case were carried out at $450 \mathrm{rpm}$ for $5 \mathrm{~h}$ to $50 \mathrm{hrs}$.

\begin{tabular}{|c|c|c|c|c|c|c|c|}
\hline Run & $\begin{array}{l}\text { Ethanol } \\
\text { (vol. \%) }\end{array}$ & $\begin{array}{l}\text { Methylethylketone } \\
\text { (vol. \%) }\end{array}$ & $\begin{array}{l}\text { Toluene } \\
\text { (vol. \%) }\end{array}$ & Run & $\begin{array}{l}\text { Ethanol } \\
\text { (vol. \%) }\end{array}$ & $\begin{array}{l}\text { Methylethylketone } \\
\text { (vol. \%) }\end{array}$ & $\begin{array}{l}\text { Toluene } \\
\text { (vol. \%) }\end{array}$ \\
\hline $\mathbf{R 1}$ & 70 & 30 & - & R7 & 30 & 30 & 40 \\
\hline R2 & 60 & 40 & - & R8 & 40 & 40 & 20 \\
\hline $\mathbf{R 3}$ & 50 & 30 & 20 & R9 & 80 & - & 20 \\
\hline R4 & 30 & 40 & 30 & R10 & 50 & - & 50 \\
\hline R5 & 40 & - & 60 & R11 & 60 & - & 40 \\
\hline R6 & 100 & - & - & R12 & 70 & - & 30 \\
\hline
\end{tabular}

The mixture doped with 3.5 wt. $\% \mathrm{Y}_{2} \mathrm{O}_{3}$ and the impact of various surfactants formulation on powder agglomeration were tested. The agglomeration characteristics of the mixed powder during milling stage were evaluated by sedimentation tests. The gravity settling tests were performed in $15 \mathrm{~cm}$ high glass tubes. The received suspensions were at first thoroughly shaken to allow the re-suspension of possible settled solids and the movement of the sediment line through the bottom of the tube was measured.

The surface morphology of samples was observed by scanning electron microscopy (SEM) (Zeiss Evo 50).

\section{$3 \quad$ Results and Discussion}

\subsection{Effect of surfactant type on powder stability}

The impact of grinding aids type and the formulation of them on milling efficiency analysed by sedimentation tests. As can be seen from Fig 1, within the all formulations, lowest sedimentation rate was obtained by ethanol: toluene system of 70: 30 . The measured highest non-compacted sedimentation height of the suspension under this condition revealed that 
the powder particles during milling is more stable. This results can be attributed the minimizing of cold welding between the powder particles and hence decreasing the agglomeration. Although, this result confirms the usage of the ethanoltoluene mixture is positively affect the true milling of the powders at milling stage, to provide the milled powders as desired finesse with a stable form, the uses of dispersant was also performed in further experiments. In these tests, oleic acid, STPP (sodium tripolyphosphate), PEG (polyethyleneglicol, M.W. 8000) and PVP (polyvinylpyrolidon) was concerned as a most suitable dispersant according the literature review.
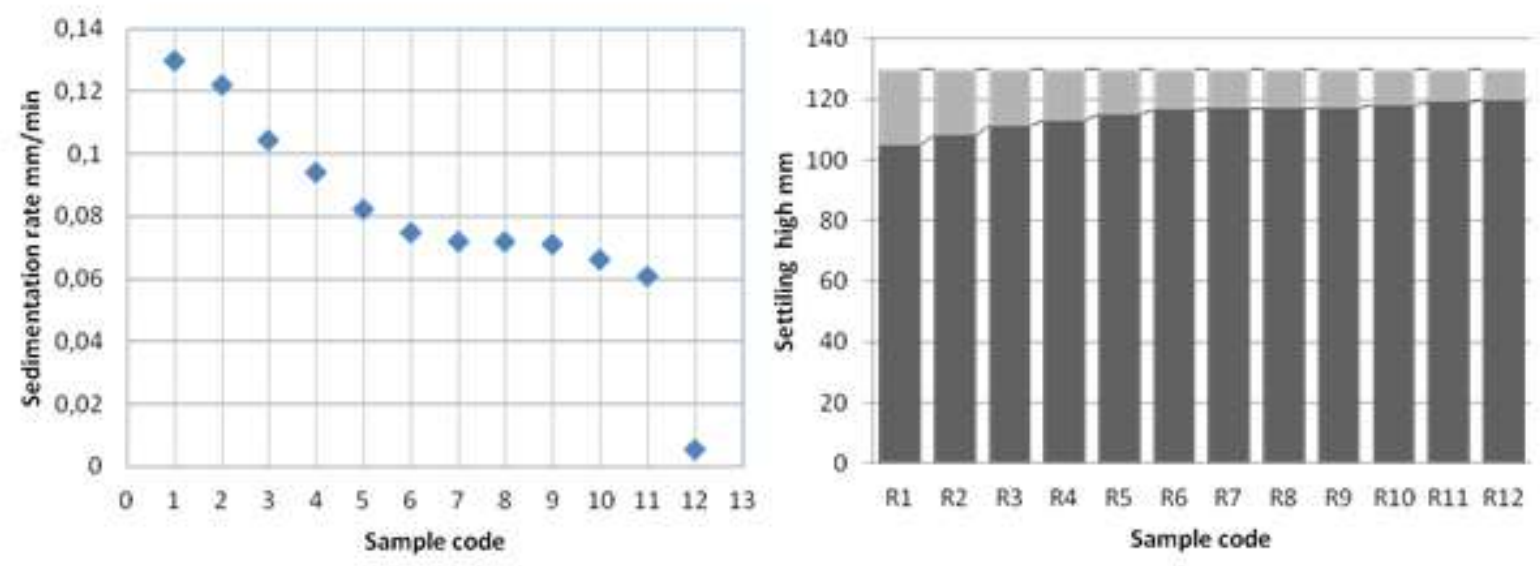

Figure 1. Variation of settling rate of the suspension (a) and sedimentation height as a function of time for different kinds of solvent (b)

The results of sedimentation tests were given at Figure 2. According to the result, it was found that the binary solvent system of ethanol and toluene with $3 \mathrm{wt}$ \% addition of PVP shows the most dispersed behaviour.

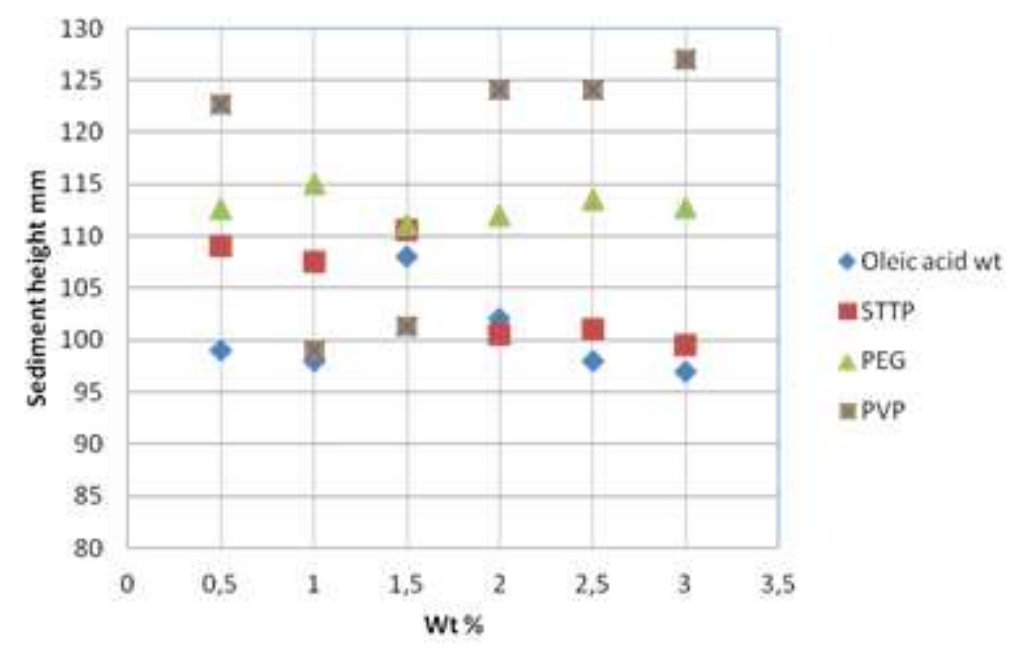

Figure 2. Effect of disperser amount on sedimentation height

\subsection{Fineness of product}

The effect of milling time on the particle size of the milled powders for determined surfactant formulations was performed by two different methods, dynamic light scattering and BET. The average particle size of the milled powders determined by these method is given in Fig. 3. 


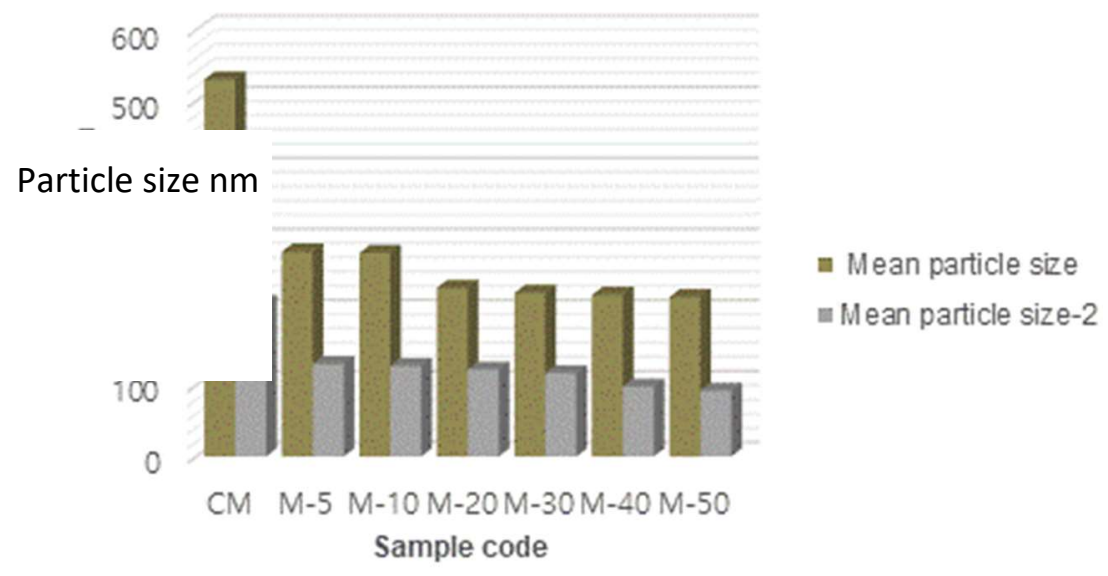

Figure 3. Grain size variation of the powders according to milling time

Figure 3 revealed the powder particle size differences of the milled powders according the employed routes, routes one and two. Compared the conventional way, the grinding and dispersant aids milled resultant with smaller particle size and more homogenous size distributions for both measurement methods. The determined remarkable size difference between CM to M5-M50, clearly indicate the positive contribution effect of surfactant modified grinding on the powder particle size. It also found that, for surfactant modified milling, the particle size of the milled powders decreases steadily with increasing the revolution speed from $300 \mathrm{rpm}$ to $450 \mathrm{rpm}$ and milling time from 5 to $50 \mathrm{hrs}$., however, for dynamic light scattering method, this effect was found to be very limited especially for the increased milling time of 20 to $50 \mathrm{hrs}$. This could be attributed the complexity of true measurement of fines particles (below $100 \mathrm{~nm}$ ) by this method [21]. During milling, the surface energy of the particles increases with decreasing grain size which cause destabilization of the particles with smaller grain sizes. The possibility of the measurements of agglomerate dimension in place of grain size needs to further verification of these results.

In the second method, the measured BET values were used to calculate the grain size of the powders. The following formulation was used mean particle size of $\left(\mathrm{D}_{\mathrm{BET}}\right)$ of the powders and the result is given in Fig. 3.

$$
\mathrm{d}=6 / \text { [surface area (BETs) x } \boldsymbol{\delta}
$$

Where $\boldsymbol{d}$ is grain size, BETs is surface area and $\boldsymbol{\delta}$ is density of powder

\subsection{Morphology}

The SEM images of the CM and MX are given in Fig. 4. As can be seen from Fig. 4.-a, the CM sample has completely different grain size morphology. The recognizable presence of course $(1 \mu \mathrm{m})$ grains together with fine (50 $\mathrm{nm}$ ) particles clearly indicates the heterogeneous grain size distribution of the sample compared the MX samples. On the other hand, the particle size differences of the MX powders for increased milling times were not clearly identified throughout the Fig. 4 b-to g, nevertheless, the visible agglomerated particles for M50 (Fig.4-g) could be attributed the increased surface energy of grains with increasing milling time. This possibly cause the increasing of the adhesive force between particles and hence reduced the milling efficiency even prolonged milling time and surfactants usage, hereby limited the further reduction of grain size. 
As previous reported by Balaz et al, the distance between particles and the number of contacts plays an important role in the appearance of adhesion. In real poly-disperse systems the presence of very fine particles along with relative coarse particles will greatly promote the formation of aggregates, and this accounts for the marked tendency for aggregation in milled products that have a broad range of particle sizes. Plastic deformation at contact points greatly increases both the area of the adhesion forces and, thereby increases the strength, compactness, and resistance to mechanical effects of particle agglomerates [3].
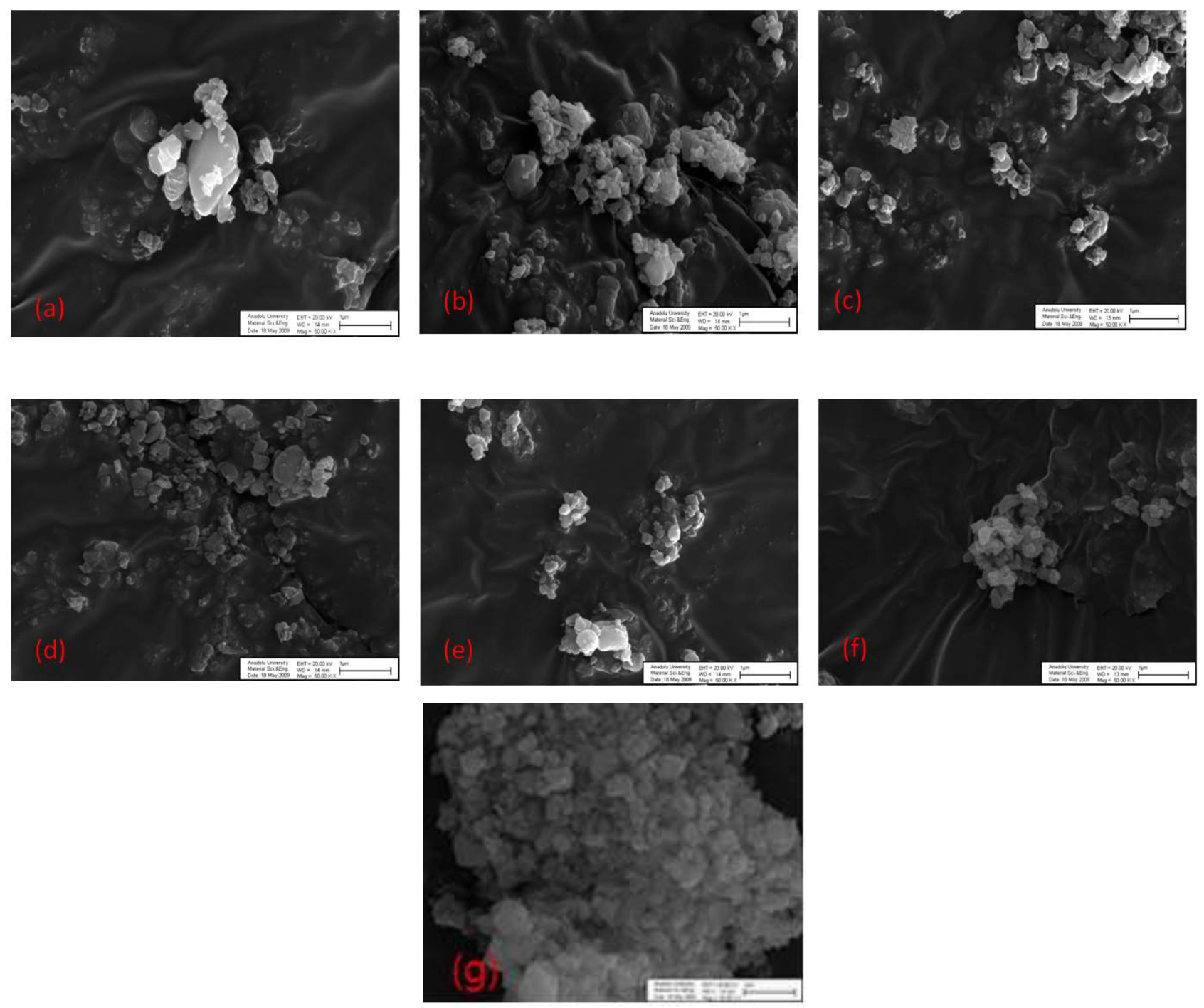

Figure 4. SEM images of samples; a-CM, b-milled at $5 \mathrm{hrs,} \mathrm{c-milled} \mathrm{at} 10 \mathrm{hrs,}$ d-milled at $20 \mathrm{hrs,} \mathrm{e-milled} \mathrm{at} 30 \mathrm{hrs,} \mathrm{f-} \mathrm{milled} \mathrm{at} 40 \mathrm{hrs,}$ g- milled at $50 \mathrm{hrs}$.

\section{Conclusion}

In mechanical milling, one of the key parameter for effective grinding is to ensure the balance between cold welding (agglomeration) to fracturing. Particles in the nanometer size range have a strong tendency to agglomerate owing to their relatively large specific surface area, which cause enhancement of their Van der Waals interactions. Therefore, they must be stabilized against aggregation. This is frequently performed by adding surfactants into the system. According to analyses results obtained in this study, it was found that increase on milling speed and true formulation of process control agent usage remarkably affected the particles size of the milled powders compared to conventional synthesis methods. It can be suggested that under true formulation of them and increase of milling speed from 300 to 450 rpm resultant with a $45 \%$ decrease in particle size compared the conventional production way. 
Nevşehir Bilim ve Teknoloji Dergisi (2019), 9 (IMSTEC Özel Sayı),79-85

\section{References}

[1] Gleiter, H., "Nanostructured Materials, Basic concept and microstructure." Acta Mater., 48, 1-29, 2000

[2] Murty, B.S., Ranganathan, S., "Novel materials synthesis by mechanical alloying/milling." Int. Mater. Rev., 43, 101-141, 1998

[3] Balaz, P., Godocikova, E., Krilova, L., Lobotk, P., Gock, E., "Preparation of nanocrystalline materials by highenergy milling," Materials Science and Engineering A, 386, 442-446, 2004

[4] Jack, K.H., "Sialons and related nitrogen ceramics.” Mater. Sci., 11, 1135-1158, 1976

[5] Deeley, G.C., Herbert, J.M., Moore, N.C., "Dense silicon nitride.” Pow. Met., 8, 145, 1961

[6] Lukianova, O.A., Krasilnikov, V.V., Parkhomenko, A.A., Sirota, V.V., "Microstructure and phase composition of cold isostatically pressed and pressureless sintered silicon nitride. "Research Letters, 11, 148, 2016

[7] Hoffmann, M.J., "Relationship between microstructure and mechanical properties of silicon nitride ceramics." Pure Appl. Chem., 67, 939-946,1995

[8] Ekström, T., Nygren, M., “SiAION Ceramics.” J. Am. Ceram. Soc., 75, 259-276, 1992

[9] Izhevskiy, V.A, Genova, L.A, Bressiani, J.C, Aldinger, F., "Progress in SiAlON Ceramics,." J. Euro. Ceram. Soc., 20, 2275-2295, 2000

[10] Shelb, J.E, Kohli, J.T., "Rare-earth aluminosilicate glasses.” J. Am. Ceram. Soc., 73, 1, 39-42, 1990

[11] Bulic, F., Zalite, I., Zhilinska, N., "Comparison of plasma-chemical synthesized SiAlON nano-powder and conventional prepared SiAlON powder, “Journal of the European Ceramic Society, 24, 3303-3306, 2004

[12] Xu, X., Oliveira, M, Ferreira, J. M. F., "Effect of solvent composition on dispersing ability of reaction SiAlON suspensions.” Journal of Colloid and Interface Science, 259, 391-397, 2003

[13] Li, Q., Zhang, C., Komeya, K., Tatami, J., Meguro, T., Gao, L., "Nano-powders of SiAlON carbothermally produced via a sol-gel process.” Journal of Materials Science Letters, 22, 885-887, 2003

[14] Xu, X., Nishimura, T., Hirosaki, N., Xie, R,, Yamamoto, Y., Tanaka, H., "Fabrication of $\alpha-S i A 1 O N$ nano ceramics by high-energy mechanical milling and spark plasma sintering.” Nanotechnology, 16, 1569-1573, 2005

[15] Lü, Z.J., Ai, X., Zhao, J., "Preparation of agglomerate-free starting powders for TiC-reinforced $\alpha-S i A l O N$ nanocomposites.” Materials Science Forum, 471-472, 282-286, 2004

[16] Tessier, P., Alamdari, H.D., Dubuc, R., Boily, S., "Nanocrystalline $\alpha-S i A l O N$ by reactive of a $\mathrm{SiO}_{2}-\mathrm{AlN}_{\mathrm{N}}$ mixture subjected to high-energy ball milling.” Journal of Alloys and Compounds, 391, 225-227, 2005

[17] Xu, X., Nishimura, T., Hirosaki, N., Xie, R., "Fabrication of $\beta$-SiAlON Nanoceramics by High-energy mechanical milling and spark plasma sintering." Institute of Physics Publishing Nanotechnology, 16, 15691573,2005

[18] Xu, X., Nishimura, T., Hirosaki, N., Xie, R., Tanaka, H., "New strategies for preparing nano-sized silicon nitride ceramics.” J. Am. Ceram. Soc., 88, 4, 934-937, 2005

[19] Suryanarayana, C., "Mechanical Alloying and Milling.”, Progress in Materials Science, 46, 1-184, 2001

[20] Prziwara, P., Breitung-Faes, S., Kwade, A., "Impact of grinding aids on dry grinding performance, bulk properties and surface energy.” Advanced Powder Technology, 29, 416-425, 2018

[21] Randall, C. A., Van Tassel, J., Matsko, M., Bowen, C. P., "Electric Field Processing of Ferroelectric Particulate Ceramics and Composites", IEEE, 0-7803-3355-1, 189-192, 1996 